\title{
Duty-Free and Quota-Free Market Accesses for Ethiopia: An Analysis of AGOA and EBA Generalize System of Preference Initiatives
}

\author{
Eyayu Tesfaye Mulugeta \\ Senior Lecturer, Department of Economics, Addis Ababa University, Addis Ababa
}

\begin{abstract}
The export sector is considered as one of the key drivers for economic growth and transformation of Ethiopia. Despite the potential capacity to diversify export and policy reforms, Ethiopia has been facing a growing trade deficit with total imports steadily increasing while the export sector performance is stagnated .To curb this situation, the country is generally committed to regional integration and works to accede to WTO and has continued with AfCFTA negotiations. Ethiopia is also the beneficiary of AGOA and EBA Duty Free Quota Free market access in US and EU markets. There have been some attempts, in the empirical literature, to examine the effect of the DFQF preference schemes on SSA's export performance. These studies have usually relied on country level export data and mainly conducted macro panel analysis for SSA. However, to the best of our knowledge, none of the study has provided an empirical back up to the firm level micro panel analysis, particularly based on Ethiopia's firms. This study tries to fill this gap in the literature by exploring empirically whether the Ethiopia's firms have really enjoyed higher export performance since the adoption of the DFQF market access.

The descriptive analysis shows that Ethiopian export to US both under AGOA preferential scheme and no programmed claimed has been increasing. Commodity wise, Ethiopia is the AGOA beneficiary with the largest volume of exports to the United States in the Apparel and Footwear subsectors. Sesame is the most important agricultural commodity exported to US under AGOA followed by Niger Seeds. The country's export to EU under EBA has rapidly increased over the past decades .Utilization rate is very divergent across the exportable products and over time. Ethiopia largely benefits from the EBA scheme in exports of horticulture, textiles, Apparel and Clothing Accessories. Following floriculture the largest product groups traded under EBA are Article of Apparel and Clothing Accessories and made up textile articles.

For the econometric analysis panel econometric analysis with Fixed Effects Estimation technique is used as a method of analysis. The estimation result revealed that EU and US DFQF scheme has, on average, exerted a positive impact on firms export performance. But the magnitude of its effect is very minimal which is mainly driven by a low utilization rate. With regard to the sector specific effect of AGOA \& EBA arrangements, the result indicated that the export performance of textile, clothing, apparel, footwear sectors under AGOA-EBA exceed the remaining export sectors tremendously.

Overall these findings suggest that the composition of export and the utilization rate of Ethiopia under EBA and AGOA schemes are relatively low. The country exhibited less diversified portfolios at the product and sector level which limits the utilization rate. Moreover, the schemes are effectively utilized by the foreign owned companies while the share of local firms is meagre.
\end{abstract}

DOI: $10.7176 / \mathrm{JESD} / 10-15-04$

Publication date: August $31^{\text {st }} 2019$

\section{Introduction and Rationale of the Study}

Ethiopia continued to post strong and inclusive economic growth for the last decade. The annual real gross domestic product (GDP) growth rate has averaged 10.8\% since 2004/05. In addition, the high GDP growth has been relatively inclusive, as it has uplifted about 20 million people out of poverty (AFDB, 2018). The main objective of the government's development strategy, anchored on its first Growth and Transformation Plan (GTP I), was to promote this inclusive growth through massive public-driven infrastructure investments. Building on GTP I, GTP II also aims to transform Ethiopia into an industrialised middle-income country by 2025 . The plan places a key emphasis on private sector development and FDI in building an export-oriented manufacturing sector to increase both the level and diversification of exports and to support resilient growth (FDRE, 2016).

To revamp the gloomy performance of the industrial sector through improved productivity, Ethiopia has also endorsed a plan that aims at reducing poverty to $16 \%$ by 2020 from $23 \%$ in 2016 through spurring investment on selected priority industries namely chemical, metal, sugar, textile, garment, leather and agro processing (MoFEC, 2010) Towards these goals, the country has adopted the Integrated Agro-Industrial Park (IAIP) development initiative, which is being implemented by the Industrial Park Development Corporation (IPDC). Though key emphasis is given to the manufacturing sector, the share of the sector to GDP and Export has been remained low and is less than the sub-Saharan Africa average (UNDP, 2017). Evidences have also witnessed that the total factor productivity of priority industries in Ethiopia are quite low (Melaku, 2012). This is attributed to mainly the 
crowding out effect of high public investment on the private sector which leds to the widening of the external sector gap.

According to WB (2016), Ethiopia exported $\$ 1.71 \mathrm{~B}$ and imported $\$ 19.1 \mathrm{~B}$, resulting in a negative trade balance of $\$ 17.3 \mathrm{~B}$. The current account deficit remained wide owing to both poor performance of exports and continued high levels of imports - especially inputs and food products. In order to improve the current account deficit position, Ethiopia is generally committed to regional integration and works to accede to WTO, and has continued with EPA negotiations. Although several challenges remain and, therefore, the process of negotiations is slow, Ethiopia is expected to meet all of the requirements set out for accession and become a member in the near future. The country has also already signed African Continental Free Trade Area (AfCFTA) in 2018 with the aim of removing tariffs and tackle non-tariff barriers to increase competitiveness of African industrial products through harnessing the economies of scale of a continental wide market.

Ethiopia is also the beneficiary of AGOA and EBA generalized non reciprocal preferential treatment to US and EU markets. The Chinese duty-free, quota-free (DFQF) market access programme entered into force on 1 July 2010 and is accessible to the 33 LDCs including Ethiopia. According to USITC (2016/17), Ethiopia's Export to US under AGOA scheme was less than \$10 million until the year 2010 and reaches \$86 million in the year 2017. Although the country's export to US shows an increasing trend, Ethiopia has been one of the least exporters to US among AGOA eligible countries. The US and EU Non tariff barrier combined with challenges in cross-border trading, constrain Ethiopia's export to US and EU under AGOA EBA schemes. The DTIS Action Matrix (2004) has identified trade policies, legal and regulatory environment, institutions; trade facilitation are factors affecting performance of the trade sector in Ethiopia. According to the World Banks Logistics Performance Index (LPI) (2016) which measures trade logistics efficiency, Ethiopia was ranked 126st out of 160 countries and all scores are below the averages of the Sub-Saharan Africa region. A recent World Bank study assesses that Ethiopia's key logistics bottlenecks are related to complex border clearance and inland transportation. This is also supported by (OECD, 2013) stating that automation and streamlining of procedures are below the regional average.

The main objective is study is therefore, assessing the trade patterns and export intensity of Ethiopia to US and EU under AGOA and EBA initiatives respectively. Specifically, the study will assess the product coverage and preference utilisation rates of Ethiopian in both initiatives and examine the difference between DFQF user and non users in terms of firm's characteristics

\section{Methodology and Data \\ Data type and Source}

Secondary Data is used in this study. Econometrics and descriptive methods of data analysis are applied to systematically analyze the data gathered. Econometric analysis is mainly used to investigate the impact of DFQF market access on firm's performance. In the descriptive analysis section, graphs, tables, and pie charts will be used to present the data and correlation, trend analysis, t-test and growth rates will be used to analyze the data..

\section{Descriptive Analysis}

\section{Trade patterns of Ethiopia with Major Trading Partners}

Over the last decade, Ethiopia has had one of the fastest growing economies in the world, with average annual growth rates ranging from $7 \%$ to $12 \%$ (depending on data sources). The export sector is considered to be one of the key drivers for economic growth and transformation. As presented in GTP I and II documents, high export growth rates though improving the manufacturing sector's capacity, productivity, competitiveness and the investment climate are crucial in realizing high real GDP growth in Ethiopia.

Regarding the export destination, the market for Ethiopian export has shown increasing trend and reached at 140 countries. However, more than $93 \%$ of the country's export is absorbed by 30 countries. Merchandise exports in Ethiopia were diversified amongst partners; imports were also diversified. The top 19 partners accounted for 80 percent or more of exports and 14 partners accounted for 80 percent or more of imports. As shown in the figure 2 below, in the year 2017, EU becomes the major export destination of Ethiopia (30.2 percent) followed by Asia (20.5 percent) and Middle East and Israel (15.8 percent). The country's export to Africa and Latin America accounted for 17.9 percent and 8.5 percent respectively. China takes share of more than $50 \%$ from the Country's Export to Asia. China's rise created huge opportunities for Ethiopia to export its commodities at higher prices into the Chinese market, propelling its growth rates

However, China's rise has also created the challenge for Ethiopia to manage the impact of the increasing competitiveness of China's labour intensive manufactured products on its own nascent labour intensive manufacturing sectors, such as clothing and textiles, leather and footwear, electronics, and furniture (Ismail, 2011). China became Africa's largest export destination. In sharp contrast both the EU, which remains the main destination for Africa's exports, and the USA have declined as an export destination for Africa. Similarly, the vast majority of Ethiopia's imports come from Asia followed by Europe, United States and Africa respectively. Italy, Turkey and Germany are the three major sources of Ethiopia's imports from Europe. 
Figure 1: Share of main export destinations as percentage of total exports (2017)

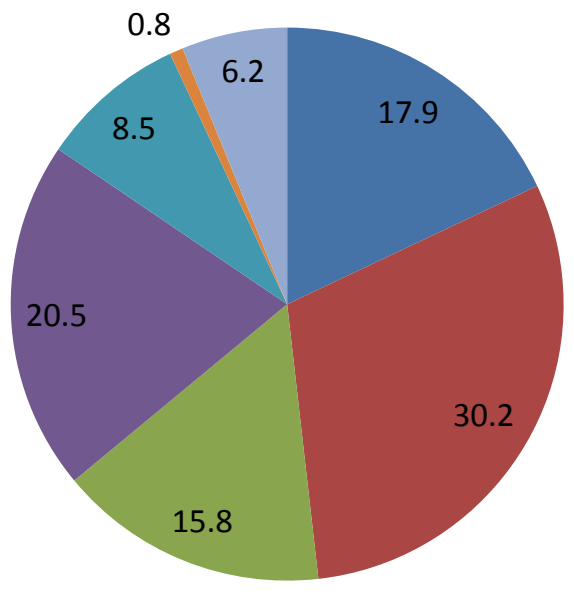

Africa

EU(28)

Middle East and Israle

Asia

America

Australia

ROW

\section{Source: own calculation based on the ITC data (2018)}

\section{Trade Relations between Ethiopia and US under AGOA GSP scheme}

Ethiopian export to US both under AGOA preferential scheme and no programmed claimed has been increasing. The country is the twelfth largest user of the AGOA program by value and it has increasingly taken advantage of the program in recent years. Since 2001 when AGOA went to effect, Ethiopia's AGOA exports mainly apparel and textiles, leather products, and horticultures.

As shown in the figure 7 below, Ethiopian Export to US with and without AGOA GSP has been increasing. Its total exports to the United States under AGOA and no programmed claimed together have risen from $\$ 125$ million in 2010 to $\$ 286$ million in 2017. During the year 2010 the share of export under AGOA scheme out of the total export to US was only $\$ 7$ million (6\%) and increased $\$ 87$ million (30\%) in the year 2017. Specifically, from the year 2011 onwards, the country's export under AGOA GSP scheme increases at a higher rate as compared to the no programe claimed export value. Accordingly for exports with no programmed claimed from $2017-$ sept.2018 increases from 160 Million USD to 193 million USD which shows increment by (20.8 \%). Similarly, the country's export to US under AGOA scheme during the same period increases from 63 million USD to 109 million USD (73.3\%). The result revealed that Ethiopia's Utilization rate of the AGOA scheme has been increasing. However, Ethiopia is not performing so much in the current utilization rates of trade preferences, For example, though Ethiopia and Vietnam have roughly the same population, Ethiopia exports less than $\$ 3$ billion to the EU and U.S while Vietnam exports \$120 billion, though it faces higher tariffs

Figure 2: Trend of Ethiopian Export to US under AGOA Scheme

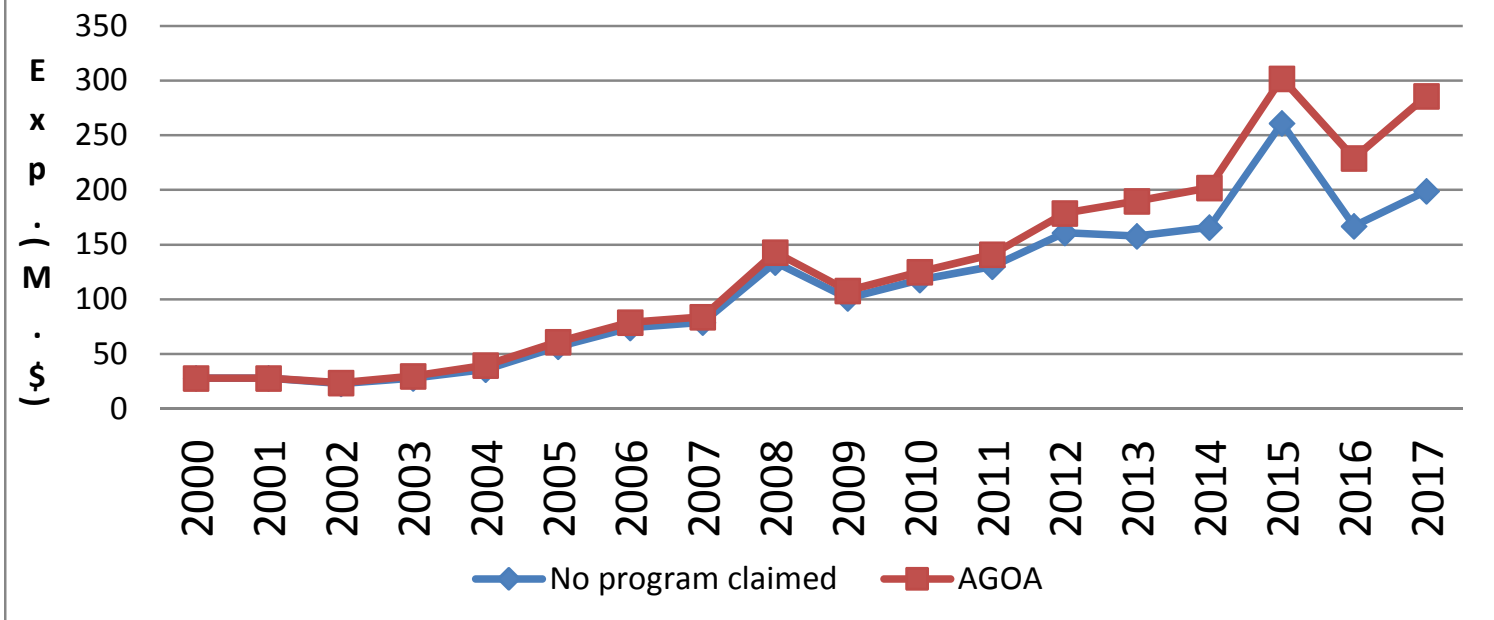

Source: Own Calculation based on USITC data (2018) Published on www.AGOA.info 


\section{Effect of AGOA Arrangement on Exports by Product Sector}

Sector wise, Ethiopia is a significant shoe producer and the top African exporter of shoes to the U.S. under AGOA. Between 2011 and 2017, Ethiopian footwear exports through AGOA increased over forty-five-fold-from $\$ 630,000$ to nearly $\$ 30$ million. In 2018, Ethiopia's shoe exports continue to grow rapidly compared to the 2017 totals (up 58 percent), making the country the first substantial AGOA footwear supplier to the United States. USAID East Africa Trade and Investment Hub facilitated a total of \$154 million export from AGOA countries from 2014 to 2016. Accordingly, Kenya is the top exporter followed by Ethiopia, Madagascar and Mauritius (The USAID Hub, 2016)

In 2016, U.S. imports under AGOA accounted for 29.3 percent of total U.S. goods imports from Ethiopia.. The leading U.S. imports under AGOA from Ethiopia were women's and children's footwear. Ethiopia's export of footwear to the United States, accounts 93 percent of U.S. footwear imports from AGOA-eligible countries in 2016. As shown in the figure 10 below, in the year 2017 and 2018 Ladies foot ware and shoe takes the largest share $(69 \%)$ of the country's export to US under AGOA scheme followed by Textile and Leather Products $(18 \%)$ and Sesame and Niger Seeds (13\%) respectively. According to Ministry of Revenue (2018) more than $90 \%$ of foot ware and shoe exported to US under AGOA scheme has been mainly supplied by The Huajian Group. The share of domestically owned firms is less than $10 \%$. As far as the agricultural commodity export to US is concerned, Sesame is the most important agricultural commodity followed by Niger Seeds.

As described in the GTP-II plan, the leather and leather products sector contributes on average about 6-8 per cent of the gross value product of all manufacturing industries and the export of leather products continues to be an important source of foreign currency earnings (UNCTAD, 2018). As shown in the fig below. Textile, leather and leather products is concerned more than $80 \%$ of the total export to US under AGOA has been supplied by NEW WING ADDIS SHOE FACTORY PLC and other big foreign owned exporters the remaining is supplied by domestically owned leather and shoe producers. This reveals that AGOA scheme is effective in attracting FDI and the arrangement has been utilized by foreign owned companies while the participation of local firms in utilizing the scheme is low.

Figure 3: Commodity Composition of Ethiopian Export to US under AGOA scheme (Received Certificate of Origin from Ministry of Revenue 2017 and 2018)

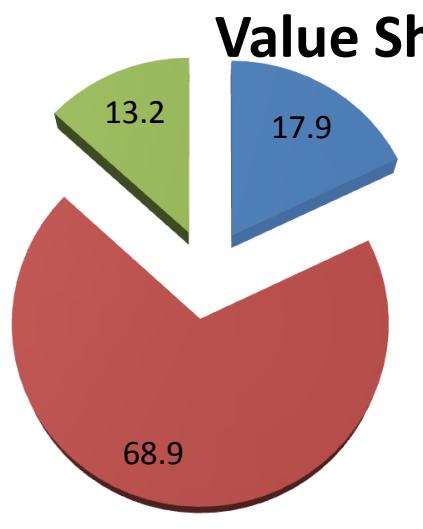

Textile and Leather Poducts

- Ladies Footware and Shoe

Sesame and Niger Seeds

Source: Ministry of Revenue, Valuation and Tariff Classification Directorate (2018)

\section{Product Composition of Ethiopian Exports to EU under EBA}

The EBA provides Ethiopia with an important competitive advantage vis-à-vis Standard GSP beneficiaries and countries that do not receive duty reduction or suspension. However, the country is increasingly facing stringent competition mainly from India, which has larger production and transport facilities, allowing the country to export larger volumes to the EU. Additionally, Ethiopia faces competition from other EBA and GSP+ beneficiaries, such as Uganda and Zambia, which both have similar export profiles.

The share of Ethiopia's EBA eligible exports in the total exports to the EU has been increasing. In 2011, this share of eligible exports was only $30.5 \%$ and increased to 56.1 per cent in the year 2016 . In 2014 out of the EURO 252.2 million GSP eligible imports from Ethiopia by EU 248.3 mill Euro was eligible for EBA preference which makes the EBA utilization rate of the country at the top 98.6 percent followed by Bangladesh $(96.1 \%)$. Ethiopia largely benefits from the EBA scheme in exports of horticulture and textiles. As shown in the fig. below, Ethiopia's EBA exports to the EU mainly fall under live trees, cutflowers, and other plants (HS Chapter 6). The floriculture sector accounted for 75 per cent of the country's total export to EU under EBA in 2016. The country's export to EU under EBA has rapidly increased over the past decades. Accordingly, between 2011 and 2016, on 
average the flower exports to the EU increased by 32.6 per cent. The second largest product groups traded under EBA are Article of Apparel and Clothing Accessories kitted and crocheted (HS 61 and 63) and made up textile articles (HS 63) which compose textile products. These exports accounted for 11 per cent and 2 per cent of the total EBA exports in 2016, respectively.

Figure 4: Composition of Ethiopia's exports under EBA by HS Chapter (2016)

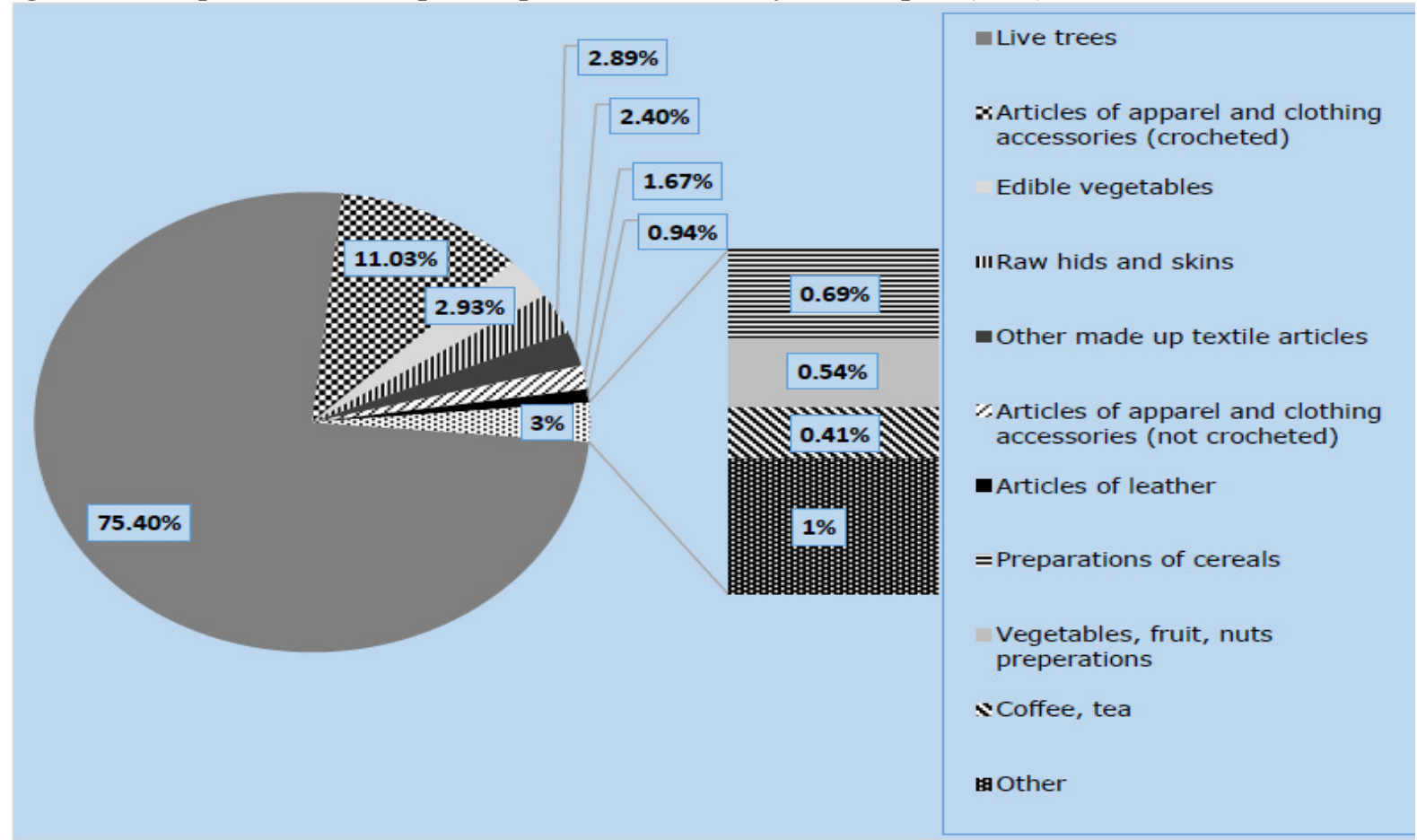

Source: European Commission Mid Term Evaluation Report (2017)

\section{Utilization Rate of Ethiopia in EU under EBA preferential Scheme}

Country's utilization rate of GSP preferences is estimated by the total value of its preferential exports divided by the total value of its eligible preferential exports. A detailed analysis of the utilization rate of Ethiopian export to EU under EBA scheme shows that the utilization rate is very divergent across the exportable products and over time. Ethiopia's EBA utilization rate has been relatively volatile - increasing from $97.1 \%$ in 2011 to $98.02 \%$ in 2013 and decline to $76 \%$ in 2015.

The highest utilization rate of 98.9 per cent can be found for Ethiopia's horticultural exports to the EU. The sector was able to rapidly expand over the past decade with support have had an important impact on expanding production and creating job opportunities in Ethiopia through exporting the EBA arrangement. The utilization rate of horticulture is relatively stable. Following Horticultural exports, high utilization can also be found for apparel and clothing accessories and other made-up textile articles which benefitted from average utilization rate of 91.6 per cent in 2016. EBA preferences are not utilised by coffee, oil seeds and oleaginous fruits and nuclear reactors, boilers and machinery exporting firms from Ethiopia. Coffee exports to the EU were worth EUR 269.97 million in 2016, making up 38 per cent of Ethiopia's total exports to the EU under MFN arrangements (not under EBA preferential scheme 
Figure 5: EBA Preference Usage of Ethiopia's Top 10 Exports (2016)

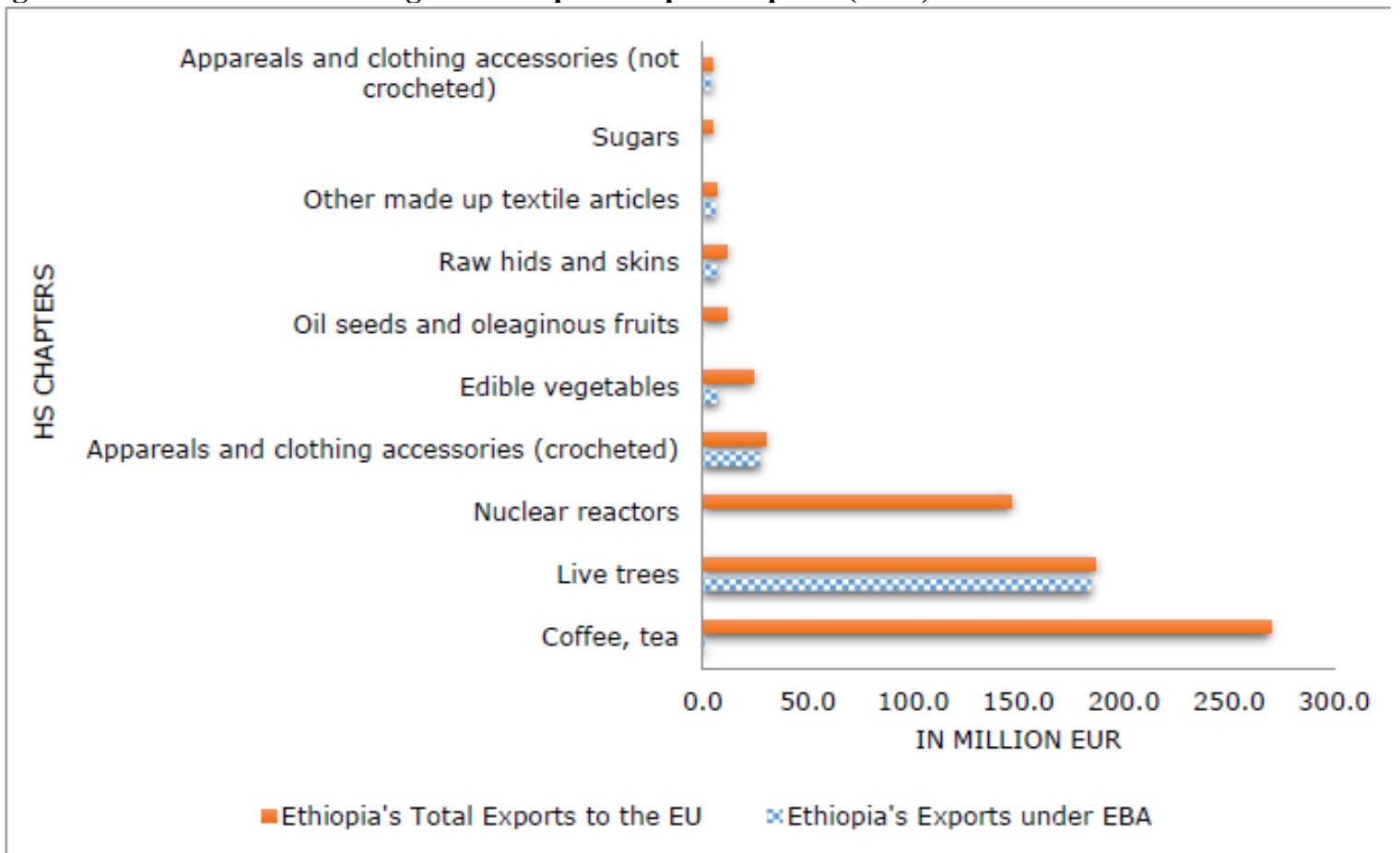

Source: European Commission Mid Term Evaluation Report (2017)

\section{Econometrics Analysis}

\section{Model Specification, Definition of Variables and Estimation Issues}

First, we will provide evidence on the magnitude of the performance gap between DFQF users and non users for a variety of firm attributes. To measure the DFQF export premium, if any, we will follow the methodology introduced by Bernard and Jensen (1995) and Bernard and Wagner (1997). The model searches for DFQF export premium, as a measure of the superiority of DFQF users relative to non-users, in terms of firm characteristics and performance. Our general estimating equation takes the following form:

$$
\begin{aligned}
& L E X_{i t}=\beta_{0}+\beta_{1} \text { ITFP }_{i t}+\beta_{2} \text { lF_SIZE }_{i t}+\beta_{3} \text { lAGE }_{i t}+\beta_{4} \text { lIMP_Rawit }_{i}+\beta_{5} \text { lCapital_Int }_{i t}
\end{aligned}
$$

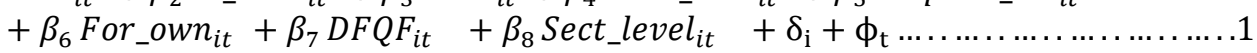

$\mathrm{Ex}_{\mathrm{it}}$ denotes the log of export value which is used to measure performance of firms, LTFP is log of total factor productivity ,LF_SIZE is log of firm size, LAGE is log of age of a firm, LIMP_Raw is log of imported raw materials value, Lcapital intensity is log of capital intensity, for_own is foreign ownership of a firm and DFQF is a dummy variable for Duty free and quota free preference. A dummy variable is used to reflect the status of the firm( 0 for non-user, 1 for user). The rationale behind this specification is that DFQF leads to better performance

The study adopted panel estimation in order to capture both between and within variations. Panel data give more informative data, more variability, less collinearity among variables, more degrees of freedom and more efficiency (Gujarati, 2004). Again, panel data allow us to account for certain unobserved individual variables that affect. The unobserved firm heterogeneity $\left(\boldsymbol{\delta}_{\boldsymbol{i}}\right)$ captures all unobserved factors that affect $\boldsymbol{E} \boldsymbol{X}_{\boldsymbol{i t}}$ but are constant over time. This is why the variable has no 't' subscript, to show for its constancy over time. The coefficient of the unobserved effect is set to one. This is because $\left(\boldsymbol{\delta}_{\boldsymbol{i}}\right)$ is unobserved and virtually has no natural unit of measurement. So it would be meaningless to try to estimate its partial effect (Wooldridge, 2002). In addition, the time dummies $\left(\left(\phi_{t}\right)\right.$ are constant across firms, but vary over time.

The pooled OLS estimation technique can used to estimate the parameters in equation (1). Under the pooled OLS regression, the parameter estimates to be consistent and unbiased. The covariance of the unobserved heterogeneity and the explanatory variables should be zero. Another way to address the unobserved effect which is adopted in the study is to employ the fixed effects transformation. This approach assumes that there is correlation between the unobserved heterogeneity and the explanatory variables and hence transforms the data into deviations from individual means. One of the disadvantage of using this fixed effect estimation is that, all time invariant variables in the specified model are omitted.

If the variables of interest are constant over time, another estimation technique referred to as the Random Effect Model (REM) is prescribed. The REM assumes that there exist zero correlation between the unobserved effects and the explanatory variables so as to estimate the parameters of any time-invariant and time-variant variable in the model. The selection between random and fixed effects is done using the Hausman test. The 
Hausman test tests for the hypothesis that the unobserved firm heterogeneity is uncorrelated with the explanatory variables. Thus, a rejection of the null hypothesis of the Hausman test suggests that the fixed effect model is the appropriate estimator for equation.

One problem confronted in estimating the export equation is the exogenous specification of the AGOA and EU-EBA preferences (Baier and Bergstrand, 2002). In the specified model AGOA and EU-EBA are represented as right hand exogenous dummy variables. However, Baier and Bergstrand (2005) showed that trade agreement dummies are not strictly exogenous owing to omitted variables, simultaneity bias, and measurement error. This study, therefore, focuses on the endogeneity of the AGOA and EU-EBA dummies. In resolving this problem, the study adopts the Hausman-Taylor (HT) estimation technique proposed by Hausman and Taylor (1981). The HT estimator controls for endogeneity by using the average values (and their deviations) of the time varying exogeneous variables as instruments for the time invariant endogeneous variables (Turkson, 2012). Egger and Pfaffermayr (2003) also indicated that a fixed effect model can be used to control for the endogeneity of trade agreements. This study, therefore, compares the results of the Fixed effects with the results from the HausmanTaylor estimation. The usefulness of the Hausman-Taylor over the REM and FEM is that, the HT allows for controlling the variables that are correlated with bilateral effects in the estimation (Turkson, 2012).

\section{Estimation Result and Discussion}

After simultaneously conducting statistical tests (F-test and Hausman test) to determine which model among the pooled, fixed, random effects and Hausman Taylor model is/are suitable for this paper, Table 2 presents the empirical findings. The result of the Hausman test in Appendix 8 rejects the null hypothesis of no correlation between the regresses and the individual heterogeneity, an F-statistic equals to 4.5 with an associated P-value amounting to 0.0000 was found. This renders the random effect model inappropriate. Therefore, the study concentrates on the parameter estimates obtained under the fixed effects and the Hausman-Taylor estimators.

The overall system indicates a good goodness of fit based on a very high coefficient of determination. Based on the results, the coefficient of determination (R2) is 0.81 indicating that $81 \%$ of the variation in export is explained by the respective explanatory variables. Except for age which shows a negative relationship (inconsistent with theoretical expectations), the results of the export model reveal that all variables are significant, with the coefficients bearing the expected signs.

Because the literature has already pointed out that Total factor productivity (TFP), Foreign owenership of a firm, Imported raw material value, Firm size, Capital intensity and other covariates do affect trade flows, we omit this discussion and focus more on the discussion about the effectiveness of the AGOA \& EBA in the form of the relationship between the preference margin and preferential exports.

Table 2 : Estimates of Export model using FE and HT

\begin{tabular}{|c|c|c|c|}
\hline Independent Variables & & ent Varia & (Exportsit) \\
\hline & $\mathrm{FE}$ & HT & FE(Sector_Level) \\
\hline $\log$ of TFP $_{\text {it }}$ & 1.026 & 1.02 & $1.05-$ \\
\hline & {$[0.000]$} & {$[0.000]$} & {$[0.000]$} \\
\hline Log of Firm_size $e_{i t}$ & 0.751 & 0.756 & 0.711 \\
\hline & {$[0.000]$} & {$[0.000]$} & {$[0.000]$} \\
\hline $\log$ of Age $_{i t}$ & -0.063 & -0.065 & -0.071 \\
\hline & [0.224] & {$[0.231]$} & {$[0.218]$} \\
\hline Log of Imp_R_mat_valit & -1.32 & -0.083 & -0.073 \\
\hline & {$[0.003]$} & {$[0.078]$} & [0.239] \\
\hline Log of Capital_intensity & 0.577 & 0.702 & 0.584 \\
\hline & {$[0.000]$} & {$[0.000]$} & {$[0.000]$} \\
\hline Foreign_ownership & 0.556 & 0.432 & 0.544 \\
\hline & {$[0.000]$} & {$[0.000]$} & {$[0.000]$} \\
\hline DFQF it $_{\text {it }}$ & 0.35 & 0.40095 & NA \\
\hline & {$[0.047]$} & {$[0.019]$} & \\
\hline Sector_level & NA & NA & $\begin{array}{l}1.13 \\
{[0.000]}\end{array}$ \\
\hline Constant & yes & yes & yes \\
\hline Time effect & yes & yes & yes \\
\hline Number of Observations & 321 & 321 & 161 \\
\hline R-squared & 0.81 & 0.81 & 0.72 \\
\hline
\end{tabular}

P values are in a square parentheses

In accordance with economic theory, a positive significant relationship was found to exist between AGOA \& EBA trade preference dummy and firms export performance. The estimate obtained from FE suggests that firms exports from Ethiopia to the EU and US, increased on average by 6 percent $\left(100\left(1-\exp ^{0.346}\right)\right)$, holding the other 
factors constant. Going by the Hausman-Taylor estimates, it also shows that AGOA_EBA agreement has a positive impact on export. That is, Ethiopia's bilateral exports under AGOA \& EBA increased by 8 percent $\left(100\left(\exp ^{0.40095}\right.\right.$ -1)), holding the other factors constant. This empirical result is also consistent with other similar studies such as Keck and Lendle(2012), Didia et al.(2015), as well as Jones and Cook(2015) who established that DFQF has a positive role to play in the increase of exports in SSA. This study therefore concludes that Ethiopia's firms exports to the EU and US have been positively influenced by the existence of AGOA \& EBA trade preference.

Despite the fact that the effect of AGOA \& EBA agreement on export performance is positive, the magnitude of its effect is very small. This suggests that both EU and USA preferences are underutilized by exporters. And from the descriptive statistics part, we have also learned that, some of the main reasons for low utilization of AGOA \& EBA preferential market access are inadequate infrastructural development (Internet Access, Power infrastructure and Internal Transport), limited eligible product coverage and administrative barriers or non tariff barriers mainly stringent Rules of Origin.. In that, empirically, the degree of improved market access measured in terms of the exports of beneficiaries to the EU and USA is less.

Sector level effect: In order to examine the magnitude of the performance gap among sectors who have DFQF market access via AGOA \& EBA, sectors are classified in to two groups. The first group contains textile, clothing, leather, apparel and footwear while the second group contains all sectors except those in the first group. To capture the performance gap an interaction term between DFQF dummy and sector specific dummy was introduced. The results show that, under all the estimation techniques, textile, clothing, leather, apparel and footwear sectors benefits much from AGOA \& EBA trade preference relative to the other sectors, , increased on average by 200 percent $\left(100\left(\exp ^{1.13}-1\right)\right)$, holding the other factors constant. From the descriptive part of our study, we also learned that with the exception of textile, apparel, footwear and clothing, most of the products covered under AGOA suffered strict Rules of Origin. Here we can argue that this interaction term may also capture the effect of less stringent/more flexible preferential rules of origin implemented unilaterally by EU and US on textile, clothing, apparel and footwear imports originating from the country under consideration during the considered period. This is not surprising given that a DFQF preference scheme could not really be effective without associated rules of origin that are simple, transparent and that facilitate market access for the products.

As shown by Brenton and Manchin (2003), the precise impact of EU and US preferential trade agreements relies on the detailed rules that the EU and US imposes to govern the eligibility for preferential treatment; especially for small countries with narrow industrial base. Four of the modelling studies namely - Frazer and Van Biesebroeck (2007), Collier and Venables (2007), Seyoum (2007), Fayissa and Tadesse (2007) - measure AGOA's impact on the apparel sector and they all find that AGOA has had a strongly positive impact on apparel exports from SSA.

\section{Concluding Remarks}

The Ethiopian economy is mainly dominated by service and agricultural sectors with a very minuscule industrial and manufacturing sector. Our exports portfolios have been dominated by agricultural goods which are suffering from price fluctuation and are income and supply inelasticity. To revamp the gloomy performance of the industrial sector through improved productivity, Ethiopian government is working to increase the export share of manufacturing sector through spurring investment on selected priority industries Though key emphasis is given to the manufacturing sector, the share of the sector to GDP and Export has been remained low and is less than the sub-Saharan Africa average.

To curb this situation, Ethiopia is generally committed to regional integration and works to accede to WTO, and has continued with AfCFTA negotiations. Moreover, Ethiopia is the beneficiary of AGOA and EBA DFQF preferential schemes provided by US and EU. There have been many factual-based statements that SSA's exports have experienced an important increase following the adoption of DFQF market access for products originating in SSA, by EU and US. There have been some attempts, in the empirical literature, to examine the effect of the DFQF preference schemes on SSA's export performance. These studies have usually relied on country level export data and mainly conducted macro panel analysis for SSA. However, to the best of our knowledge, none of the study has provided an empirical back up to the firm level micro panel analysis, particularly based on Ethiopia's firms. This study tries to fill this gap in the literature by exploring empirically whether the Ethiopia's firms have really enjoyed higher export performance since the adoption of the DFQF market access and if so, what type of export product (textile, clothing, apparel, footwear, etc) has been most affected by this decision.

The finding from our descriptive analysis revealed that Ethiopia is the AGOA beneficiary with the largest volume of exports to the United States in the Apparel and Footwear subsectors and few agricultural commodities such as Sesame and Niger Seeds. Hence, in terms of product composition and utilization rate, the country is the least contributor of Export to US under AGOA arrangement. The country's export to EU under EBA has rapidly increased over the past decades. Utilization rate is very divergent across the exportable products and over time. Ethiopia largely benefits from the EBA scheme in exports of horticulture, textiles, Apparel and Clothing Accessories. 
The result from our econometric analysis the study also show that, EU and US decision on DFQF has, on average, exerted a positive impact on firms export performance. But the magnitude of its effect is very minimal which is mainly driven by a low utilization rate. With regard to the sector specific effect of AGOA \& EBA, the result indicated that the export performance of textile, clothing, apparel, footwear sectors under AGOA-EBA exceed the remaining export sectors tremendously.

Overall these findings suggest that the composition of export and the utilization rate of Ethiopia under EBA and AGOA schemes are relatively low. Commodity wise, the country's export to these markets is limited to horticulture, Sesame, Niger Seeds, apparel and textile products. Moreover, the schemes are effectively utilized by the foreign owned companies (mainly Chinese) while the share of local exporters is meagre. Tariffs on products excluded from AGOA, especially on agricultural goods, of which Ethiopia do have a competitive advantage remain high.

\section{References}

Bartels, L. (2007). The Trade and Development Policy of the European Union. The European Journal of International Law, 18(4), 715-756.

Borchert, I. (2009). Trade Diversion under Selective Preferential Market Access. Canadian Journal of Economics, 42(4), 1390-1410.

Brenton, P., and Ikezuki, T. (2004). The Initial and Potential Impact of Preferenctial Access to U.S Market under the African Growth and Opportunity Act. World Bank Policy Research Working Paper 3262.

Brenton, Paul (2003). Integrating the Least Developed Countries into the World Trading System: The Current Impact of EU Preferences under the Everything but Arms. Policy Research working paper No. 3018, Washington, DC; World Bank.

Cipollina, M. and Salvatici, L. (2010). The trade impact of european union agricultural preferences. Journal of Economic Policy Reform, 13(1):87-106.

Cirera, X., Foliano, F., and Gasiorek, M. (2016). The impact of preferences on developing countries' exportsto the european union: bilateral gravity modelling at the product level. Empirical Economics, 50(1):59-102.

Cooke, E. F. A (2011). A Matching Approach to study the Impact of AGOA on Sub-Saharan African Countries. MPRA paper No. 34670.

Didia, D., M. Nica and G. Yu (2015) 'The Gravity Model, African Growth and Opportunity Act (AGOA) and US Trade Relations with Sub-Saharan Africa', The Journal of International Trade \& Economic Development : 122.

East Africa Trade and Investment Hub (2016), "How to Export your goods to the US Duty Free Quota Free under AGOA", USAID Economic Update

European Commission (2017), "Mid-Term Evaluation of the EU's Generalized System of Preferences (GSP) Final Interim Report “, Directorate-General for Trade , European Commission, Brussels.

FDRE (2016): "Federal Democratic Republic of Ethiopia Country Strategy Paper 2016-2020", Geneva

Herz, B. and Wagner, M. (2011). The dark side of the generalized system of preferences. Review of International Economics, 19(4):763-775.

Hoekman, B. (2005). 'Trade Preferences and Differential Treatment of Developing Countries: A Selective Survey." World Bank Policy Research Working Paper 3566.Jones V. C. (2013). 'Generalized System of Preferences: Background and Renewal Debate," Congressional Research Service, Washington, DC. http://www.dbe.com.et/homenew/BusnessPromotion/Policy/DBENewPolicyEng.pdf

Jones, J.C. and N.P.S. Cook (2015) 'The African Growth and Opportunity Act (AGOA) and Export Diversification', The Journal of International Trade \& Eco-nomic Development 24(7): 947-967.

Keck \& Lendle (2012). New Evidence on Preference Utilization.

Lederman, D., \& Özden, Ç. (2004). US Trade Preferences: all are not created equal. Documentos de Trabajo (Banco Central de Chile), (280), 1.

Leo, B., \& Ramachandran, V. (2014). Getting Serious about Underperformance of the African Growth and Opportunity Act: Policy Options for Supporting Trade Potential in Africa. Rethinking US Development Policy, Center for Global Development.Lorand Bartels(2007): The Trade and Development Policy of the European Union, The European Journal of International Law Vol. 18 no. 4

Marius Brülhart and Alan Matthews(2007): EU External Trade Policy, The European Union: Economics \& Policies, 8th edition, Cambridge University Press, 2007

Mattoo, A., Roy, D., \& Subramanian, A. (2002). The African Growth and Opportunity Act and its Rules of Origin Generosity Undermined?.

MOFED (2010) “Annual Report on Macroeocnomic Development”, Addis Ababa, Ethiopia.

OECD (2013). "Foreign Direct Investment for development; maximizing benefits, minimizing costs" Paris on Trade And Development.

Segerstrom, P. S. (2013). Trade and economic growth. In Palgrave Handbook of International Trade, pages594- 
621. Springer.

Seyoum, B. (2007). Export performance of developing countries under the Africa Growth and Opportunity Act: Experience from US trade with Sub-Saharan Africa. Journal of Economic Studies, 34(6), 515-533.

Shapouri, S., \& Trueblood, M. (2003). The African Growth and Opportunity Act (AGOA): Does it really present opportunities. In International Agricultural Trade Research Consortium (IATRC) Conference, Capri, Italy.

Spence, M. et al. (2008). The growth report: Strategies for sustained growth and inclusive development.Commission on Growth and Development Final Report, Washington, DC.

Taye HK (1999). The impact of Currency Devaluation on the Macroeconomic Performance of Ethiopia. J. Pol. Model. 215:481- 496

Turkson, F. E. (2012). Trade Agreements and Bilateral Trade in Sub-Saharan Africa: Estimating the Trade Effects of the EU-ACP PTA and RTAs. CREDIT Research Paper (No. 12/07).

UNCTAD (2012). Handbook on duty-free quota-free (dfqf) and rules of origin. United Nations Conference

UNCTAD (2013). “Global Value Chains: Investment and Trade for Development” World Investment Report 2013. Geneva: United Nations

UNCTAD (2015): "World investment report: Trends and Determinants." UN, New York and

UNCTAD(2018) "HANDBOOK On Duty-Free and Quota-Free Market Access and Rules of Origin For Least Developed Countries", United Nations Conference for Trade and Development, Geneva.

Valdes, Alberto (1986), 'Exchange Rates and Trade Policy: Help or Hindrance to Economic Growth', in Agriculture in a Turbulent World Economy, Proceedings of the Nineteenth International Conference of Agricultural Economists, Gowe

World Bank (2016) "Doing Business Report on Ethiopia”, World Bank Group.

World Bank (2016) "Strengthening Export Performance through Improved Competitiveness", 3 rd, 